\title{
The Pine Saddle site (3PL1080) in the Ouachita Mountains, Polk County, Arkansas
}

Timothy K. Perttula

Heritage Research Center, Stephen F. Austin State University

Bo Nelson

Heritage Research Center, Stephen F. Austin State University

Follow this and additional works at: https://scholarworks.sfasu.edu/ita

Part of the American Material Culture Commons, Archaeological Anthropology Commons, Environmental Studies Commons, Other American Studies Commons, Other Arts and Humanities Commons, Other History of Art, Architecture, and Archaeology Commons, and the United States History Commons

Tell us how this article helped you.

This Article is brought to you for free and open access by the Center for Regional Heritage Research at SFA ScholarWorks. It has been accepted for inclusion in Index of Texas Archaeology: Open Access Gray Literature from the Lone Star State by an authorized editor of SFA ScholarWorks. For more information, please contact cdsscholarworks@sfasu.edu. 


\section{The Pine Saddle site (3PL1080) in the Ouachita Mountains, Polk County,}

Arkansas

\section{Creative Commons License}

\section{(c) (1) (8)}

This work is licensed under a Creative Commons Attribution-NonCommercial 4.0 International License 


\title{
The Pine Saddle site (3PL1080) in the Ouachita Mountains, Polk County, Arkansas
}

\author{
Timothy K. Perttula and Bo Nelson \\ Archeological \& Environmental Consultants, LLC
}

Introduction

Novaculite was procured and knapped by aboriginal Indian populations living in southwestern Arkansas for thousands of years (see Trubitt et al. 2003), and there are numerous prehistoric novaculite quarries in the Ouachita Mountains (Etchieson 1997). In Late Archaic times, this desirable material was widely traded and exchanged with other groups to the south, east, and west, particularly with the peoples living at the Poverty Point site and environs in the lower Mississippi valley in northern Louisiana (see Jeter and Jackson 1994:159-166). Later groups such as the Caddo also made considerable use of this material, since it was in their traditional homelands, and many habitation sites and mound centers in the region contain quantities of novaculite lithic debris and tools. Other local materials were also chosen for lithic tool manufacture, such as Big Fork chert, a distinctive black chert. Abundant amounts of novaculite and Big Fork chert are also found apparently in nondomestic Caddo contexts on lithic workshops and camp sites in the Ouachita Mountains, and one such site is discussed in this article.

\section{The Pine Saddle site}

The Pine Saddle site (3PL1080) is located in a unique landform in this part of the southern Ouachita Mountains, namely a saddle (1340 feet amsl) between two linear ridges 20-40 feet higher in elevation (Figure 1). There are several intermittent drainages to the northeast, west, and south of the site; these drain into Twomile Creek, a tributary to the Mountain Fork River, which flows south to its confluence with the Little River in southeastern Oklahoma. The saddle area covers about 6400 square meters (1.6 acres), and is wooded with a stand of pine trees. The overall surface visibility on the landform is poor.

Fourteen shovel tests were excavated across the landform during a recent archeological survey of a tract of land for the Ouachita National Forest (Perttula and Nelson 2004a), and all 14 contained prehistoric archeological materials from $0-40 \mathrm{~cm}$ bs in Sherless-Bengal sediments. One shovel test (ST 220) has a dark grayish-brown (10YR 3/2) loam deposit with charcoal flecks that may represent a patch of prehistoric midden deposits, but otherwise midden deposits are absent, as are pieces of ceramic vessels, animal bones, or other obvious signs of domestic use of the Pine Saddle site. That shovel test also has $1.36 \mathrm{~kg}$ of fire-cracked rock, probably evidence of either the mass processing of plant foods by the prehistoric occupants of the Pine Saddle site, or the use of heated rock for the heat-treating of novaculite. Four other shovel tests in the saddle (ST 221, ST 223, ST 230, and ST 231) also have fire-cracked sandstone rocks weighing another $2.1 \mathrm{~kg}$. These same shovel tests also have small amounts of wood charcoal.

A column of $200 \mathrm{~g}$ sediment samples were obtained from ST 232 for Oxidizable Carbon Ratio (OCR) dating (see Frink 1992, 1994, 1995, 1999) of the archeological deposits. The only other datable material at the Pine Saddle site are a few small pieces of wood charcoal, but they did not occur in reliable contexts. We have obtained good results from the OCR dating of archeological deposits at several other Caddo sites in the 


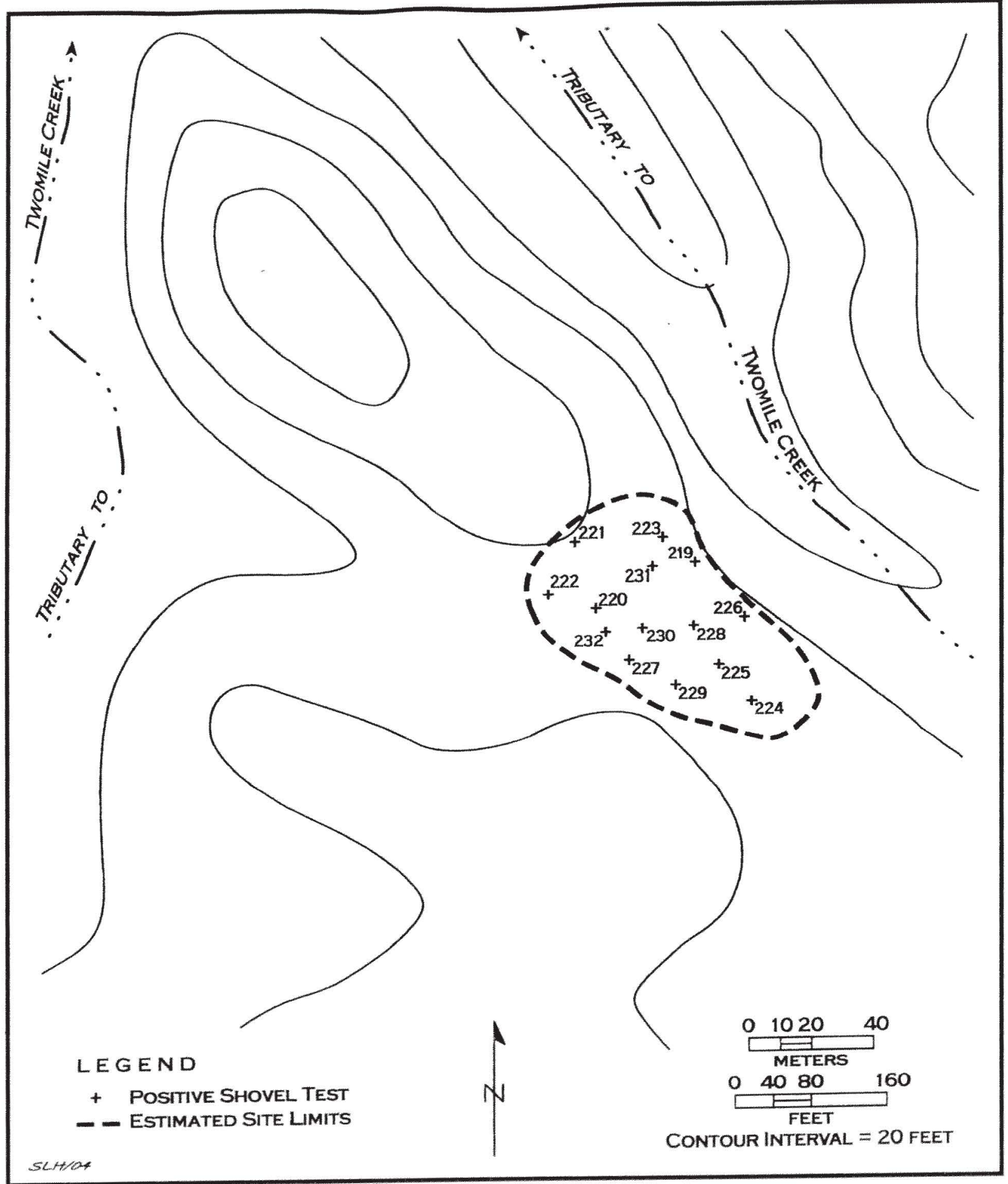

Figure 1. The Pine Saddle site (3PL1080),

southern Ouachita Mountains (Pertula and Nelson 2004b: Tables 2, 7, and 10), and we decided to pursue that dating option.

Based on differences in the frequency of coarse and very coarse particles in the different soil samples, changes in $\mathrm{pH}$ and \% Organic Carbon, and \% Oxidizable Carbon, the OCR dates from several pedogenic events 
point to two different prehistoric occupations by Caddo peoples at the Pine Saddle site (Table 1). The first dates to about 440 years ago (A.D. 1510), and corresponds to the upper part of the archeological deposits. The earlier occupation is focused on the OCR sample from $33-35 \mathrm{~cm}$ bs, and dates to about 1010 years ago (A.D. 940).

The different clusters of samples [i.e., $3-5 \mathrm{~cm}$ and 8-10 $\mathrm{cm}$ samples] represent "packages of soils related by the pedogenic history. The highlighted data sets represent the youngest pedologic event of the particular package" (Douglas Frink, June 18, 2004 personal communication).

Table 1. OCR dates from the Pine Saddle site (3PL1080).

\begin{tabular}{|c|c|c|c|}
\hline $\begin{array}{l}\text { Sample } \\
\text { Depth } \\
\text { (cm bs) }\end{array}$ & $\begin{array}{l}\text { Sample } \\
\text { No. }\end{array}$ & $\begin{array}{l}\text { OCR date } \\
\text { (B.P.) }\end{array}$ & $\begin{array}{c}\text { Conventional Age } \\
\text { (A.D.) }\end{array}$ \\
\hline $3-5$ & ACT-7039 & 192 & A.D. 1758 \\
\hline $8-10$ & ACT -7040 & 398 & A.D. 1552 \\
\hline $13-15$ & ACT-7041 & 442 & A.D. 1508 \\
\hline $18-20$ & ACT-7042 & 587 & A.D. 1363 \\
\hline $23-25$ & ACT-7043 & 937 & A.D. 1013 \\
\hline $28-30$ & ACT-7044 & 1026 & A.D. 924 \\
\hline 33-35 & ACT-7045 & 1014 & A.D. 936 \\
\hline $38-40$ & ACT-7046 & 1386 & A.D. 564 \\
\hline
\end{tabular}

Note: the highlighted samples represent dated pedogenic events

\section{Lithic Artifacts from the Pine Saddle site}

No temporally diagnostic lithic or ceramic artifacts were recovered in our work at the Pine Saddle site, only broken tools, a hammerstone, and many pieces of novaculite lithic debris. The mean density of prehistoric lithic artifacts is high, at 23.1 artifacts per positive shovel test (approximately 185 artifacts per square meter). The highest densities (between 43-64 artifacts per shovel test, or 344-512 artifacts per square meter) of prehistoric artifacts are in the central part of the saddle (see Figure 1), as are most of the shovel tests that have fire-cracked rocks and preserved wood charcoal. If the densities from these shovel tests can be extrapolated across the entire site, it suggests that the Pine Saddle site contains about 1,200,000 lithic artifacts! Clearly, a significant amount of lithic knapping of novaculite and Big Fork chert by Caddo peoples took place at the site between A.D. 940 and A.D. 1510.

Two chipped stone tools (both biface fragments) and a hammerstone were recovered in shovel testing at the Pine Saddle site. The first biface (ST $228,0-12 \mathrm{~cm}$ bs) is a thin biface fragment $(8.37 \mathrm{~mm})$ of heat-treated gray novaculite, formed by both hard hammer and soft hammer flaking; the edges are sinuous and apparently the biface is not from a finished bifacial tool. It measures $28.73 \mathrm{~mm}$ in width and $8.37 \mathrm{~mm}$ in thickness. The 
second biface (ST 231, 0-20 cm bs) is a thick biface fragment $(10.64 \mathrm{~mm})$ of Big Fork chert, formed by hard hammer flaking; there is no cortex remaining on the piece, but the edges are crushed from knapping.

The hammerstone (ST 230, 20-27 cm) is made from a dense sandstone. It has a flat and smoothed poll end, with edge abrading along two edges of the tool. Opposite the poll end, the tool has both crushing and abraded areas, and there is a small area of pecking on one face; the latter is probably the product of the crushing and pulverizing of plant materials, such as seeds or nutshells. The hammerstone is $102.78 \mathrm{~mm}$ in length, $78.17 \mathrm{~mm}$ in width, and $45.77 \mathrm{~mm}$ in thickness.

Eighteen pieces of lithic debris were noted on the surface of the Pine Saddle site. From the shovel testing, we recovered four flake cores, one each of white novaculite, dark gray novaculite, Big Fork chert, and blue-gray chert (probably a weathered variety of Big Fork chert). There were a wide variety of lithic raw materials in the lithic debris, particularly Big Fork chert $(n=118,37 \%)$, gray novaculite $(n=99,31 \%)$, dark gray novaculite $(\mathrm{n}=36,11 \%)$, white novaculite $(\mathrm{n}=29,9 \%)$, and blue-gray chert $(\mathrm{n}=21,7 \%)$ (Table 2$)$.

About $20 \%$ of the Big Fork chert lithic debris are secondary decortification flakes, compared to about $1 \%$ of the novaculite lithic debris, and it seems likely that the debris from each of these raw materials were the product of different stages in the process of tool production at the Pine Saddle site. Big Fork chert was apparently brought to the site in rougher form than the novaculite, and more knapping of cores and rough bifaces had to be done to remove the outer cortex and thin the pieces meant for tools. The novaculite flakes were predominantly the product of final biface reduction and tool manufacture, or at least the cobbles, cores, and bifaces knapped at the site had had the outer rind removed at another location, probably at one of the novaculite quarries or workshops.

This differential knapping of Big Fork chert versus novaculite raw materials (at least all colors except for red) is not just characteristic of the Pine Saddle lithic debris assemblage, but generally holds at the sites across the Twomile Creek project area (Perttula and Nelson 2004a). Taken together, more than 14\% of the Big Fork lithic debris from the project area sites are primary or secondary decortification flakes. By comparison, less than

Table 2. Flake types and raw materials in the Pine Saddle site lithic debris.

\begin{tabular}{|c|c|c|c|c|c|}
\hline Raw Material & Primary & Secondary & Tertiary & Thinning & Blade \\
\hline Big Fork chert & - & 22 & 94 & 1 & 1 \\
\hline Blue-gray chert & - & - & 20 & - & 1 \\
\hline Dark gray chert & - & - & 4 & - & - \\
\hline White novaculite & - & - & 29 & - & - \\
\hline Gray novaculite & - & - & 97 & 2 & - \\
\hline Dark gray novaculite & - & 1 & 35 & - & - \\
\hline Dark gray-black nov. & - & - & 1 & - & - \\
\hline Red novaculite & - & - & 3 & - & - \\
\hline White-black novaculite & - & 1 & - & - & - \\
\hline Black novaculite & - & - & 2 & - & - \\
\hline Heat-treated novaculite & - & - & 3 & - & - \\
\hline
\end{tabular}


$1 \%$ of the gray novaculite flakes are cortical; none of the white novaculite flakes are cortical, and only $3.7 \%$ of the dark gray novaculite flakes are cortical pieces. Other lithic raw materials with relatively high percentages of cortical flakes are gray chert $(14 \%, \mathrm{n}=7)$ and red novaculite $(14 \%, \mathrm{n}=14)$.

Thinning flakes are not well-represented in the Pine Saddle lithic debris assemblage (see Table 2), accounting for less than $1 \%$ of the sample. They are not particularly abundant at any of the other 26 prehistoric sites recorded along Twomile Creek and tributaries (Pertula and Nelson 2004a), and they only comprise $2.9 \%$ of the entire lithic debris sample from these prehistoric sites. However, the frequency of bifacial thinning activities appears to be limited at all the sites, regardless of the kind of lithic raw material being worked, as among the four principal raw materials only $3.3 \%$ of Big Fork chert flakes are thinning flakes compared to $3.3 \%$ of the gray novaculite flakes; $3.7 \%$ of the dark gray novaculite flakes; and $1 \%$ of the white novaculite flakes. This in turn suggests that the long-term goal of knapping at the Pine Saddle site by Caddo knappers, and at other nearby sites, was primarily the production of flakes of Big Fork chert and novaculite that would be suitable for use as flake tools and as blanks for arrow point manufacture.

\section{References Cited}

Etchieson, M.

1997 Prehistoric Novaculite Quarries in the Ouachita Mountains, Paper presented at the Society for American Archaeology Meetings, Nashville, Tennessee.

Frink, D. S.

1992 The Chemical Variability of Carbonized Organic Matter through Time. Archaeology of Eastern North America 20:6779.

1994 The Oxidizable Carbon Ratio (OCR): A proposed solution to some of the problems encountered with radiocarbon data. North American Archaeologist 15(1):17-29.

1995 Application of the Oxidizable Carbon Ratio (OCR) Dating Procedure and its Implications for Pedogenic Research. In Pedological Perspectives in Archaeological Research. SSSA Special Publication 44. Soil Science Society of America, Madison.

1999 The Scientific Basis of Oxidizable Carbon Ratio (OCR) Dating. Society for American Archaeology Bulletin 17(5):3237.

Jeter, M. D. and H. E. Jackson

1994 Poverty Point Extraction and Exchange: The Arkansas Lithic Connections. Louisiana Archaeology 17:133-206.

Perttula, T. K. and B. Nelson

2004a Archeological Survey Investigations of 1239 Acres in the Mena/Oden Districts of the Ouachita National Forest, Polk County, Arkansas. Report of Investigations No. 65. Archeological \& Environmental Consultants, LLC, Austin.

2004b Certain Caddo Sites in the Ouachita Mountains of Southwestern Arkansas. Caddoan Archeology Journal 13 (3/4):2156.

Trubitt, M. B., T. Green, and A. Early

2003 A Novaculite Quarry Research Design. MS on file, Arkansas Archeological Survey, Fayetteville. 